\title{
Reproduction of African Tigrine Frog Hoplobatrachus occipitalis in Banco National Park (Ivory Coast)
}

\author{
Blayda Tohé1, N'Guessan Emmanuel Assemian'², N'Goran Germain Kouamé3

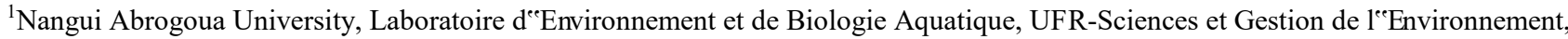 \\ 02 B.P. 801 Abidjan 02, Ivory Coast \\ ${ }^{2}$ Jean Lorougnon Guédé University, Department of Biology and Animal Physiology, UFR-Environment, B.P. 150 Daloa, Ivory Coast \\ ${ }^{3}$ Jean Lorougnon Guédé University, Department of Biology and Animal Physiology, UFR-Environment, B.P. 150 Daloa, Ivory Coast
}

\begin{abstract}
The reproduction of Hoplobatrachus occipitalis (Dicroglossidae) was studied in the Banco National Park (BNP) from Ivory Coast. After weighing and dissection of different specimens, male gonads and female gonads are weighed. The eggs of female gonad were counted and measured to the nearest millimeter. The sizes at first sexual maturity in females and males are $124.5 \mathrm{~mm}$ and $95 \mathrm{~mm}$ respectively. The overall sex ratio evaluated for the BNP is in favor of males (1/2.08). The breeding period of this species is at the early rainy season. The female of this species has heterogeneous gonads, which means fractional oviposition.
\end{abstract}

Keywords: Reproduction, Hoplobatrachus occipitalis, First sexual maturity, Ivory Coast

\section{Introduction}

The frogs are an important source of animal protein in Africa [1]. In the western region of Cameroon as well as in the eastern part of Nigeria, [2] report that, even tadpoles are captured for food. This indicates the overexploitation of this resource by rural communities who are fighting daily to search income generating activities. In addition, it has been noted [2] a flourishing trade frogs in many West African countries such as Burkina Faso, Benin and Nigeria, where these animals are sold dried or fried. The species most commonly consumed is Hoplobatrachus occipitalis whose large quantities are taken from the natural environment. Indeed, [3] reports that the global market for human use is made up by wild frogs taken from the wild where several species are exploited. Actually, no regulation governs the exploitation of these animals in the Sub-Saharan region. The Livestock frogs would be an alternative to ensure the sustainability of the resource. The mastery of this breeding necessarily involves mastering the biology of the species. In Côte d'Ivoire, little information is available concerning its reproduction. Particularly in the Banco National Park (BNP), only one publication [4] relates its diet. Regarding its reproduction, the results available in this ecosystem refer only to its pace of activity songs [5]. The present study aims to highlight some traits of the reproduction of $H$. occipitalis in BNP.

\section{Materials and Methods}

\subsection{Study Site}

The Banco National Park (Figure 1) with an area of 3474 hectares [6], is a protected forest in the heart of Abidjan, the economic capital of Ivory Coast. This park is characterized by two dry seasons and two rainy seasons. A longer great dry season lasts from December to March is followed by the period with highest precipitation from April to July. A minor dry season lasts from August to September whereas the minor rainy season stretches from October to November. The mean annual precipitation sums to about $2000 \mathrm{~mm}$. The mean annual temperature in the Banco National Park is $26.4^{\circ} \mathrm{C}$.

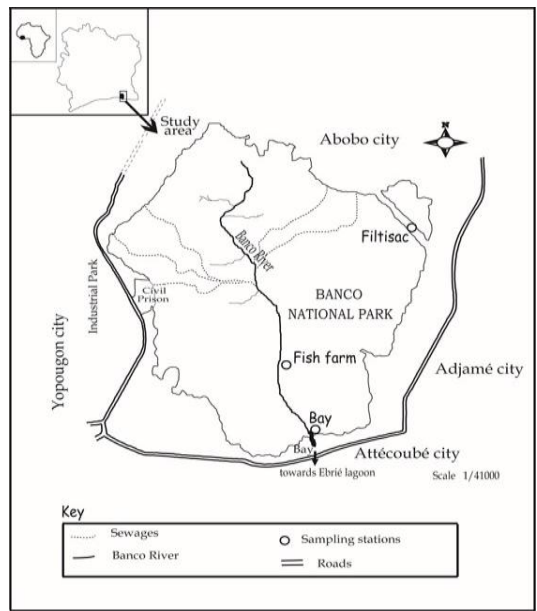

Figure 1: Map of the Banco National Park showing the sampling stations

In this ecosystem, the reproduction of Hoplobatrachus occipitalis was held in three degraded sites where encountered populations were abundant. The first site, Bay $\left(05^{\circ} 21^{\prime} \mathrm{N}\right.$ and $\left.04^{\circ} 02^{\prime} \mathrm{W}\right)$, located at the main entry in the south of the park, is an open zone covered by grass, heavily degraded and water polluted due to the "Fanico" launderers, people that use the Banco river for religious rituals or car washing. The second site, Fish farm $\left(05^{\circ} 23^{\prime} \mathrm{N}\right.$ and $04^{\circ} 03^{\prime}$ $\mathrm{W})$, is a central clearing with 16 artificial ponds, partly open, partly heavily degraded and only with shallow water, temporary and perennial waters (the latter stocked with Tilapia fish). This site is characterized by flowing creeks 


\section{International Journal of Science and Research (IJSR) \\ ISSN (Online): 2319-7064}

Index Copernicus Value (2013): 6.14 | Impact Factor (2014): 5.611

which crosses the central clearing and runs along the forest, surrounded by a swampy forest, the Banco River and bamboo plots. The third site, Filtisac $\left(05^{\circ} 24^{\prime} \mathrm{N}\right.$ and $\left.04^{\circ} 01^{\prime} \mathrm{W}\right)$, is located in the north of the park and characterized by a heavily degraded forest with open canopy, three larger ponds that are polluted due to the nearby mechanic quarters, a factory, corn, cassava and yam plantations.

\subsection{Sampling and analysis}

Hoplobatrachus occipitalis specimens were captured with a dip net during the day and night from April 2004 to March 2005. After identification on the basis of [7] and measuring the Snout-Vent Length (SVL) to the nearest millimeter with a caliper, the frog is anesthetized with chlorobutanol and its gonad is collected. It is then weighed and kept in pill dispensers with $70 \%$ ethanol for laboratory studies.

\subsection{Sex ratio (SR)}

The sex ratio is the proportion of males or females in the population of a given species. It may be expressed as a percentage in the number of males or females compared to the sampled population [8]:

$$
\begin{aligned}
S R & =\frac{M}{M+F} \times 100 \\
\text { or } S R & =\frac{F}{M+F} \times 100
\end{aligned}
$$

$M=$ number of males; $F=$ number of females

\subsection{Size at First Sexual Maturity}

The size at first sexual maturity (or size at first reproduction or L50) is a standard average length from which $50 \%$ of individuals are able to reproduce [9]-[11]. It is defined from the size classes. These are based on the Sturge's formula [12]. Interval of classes $=\frac{\text { maximal size }- \text { minimal size }}{\text { nomber of classes }}$

Number of classes $\mathrm{N}=1+3.3 \log n$ with $n$ is the number of individuals for the sample considered. This method is widely used in fish [9]-[11], [13]. It takes account only mature individuals and their cumulative percentages. To get it, you wear the different median of the size classes in abscissa and the cumulative percentage of mature individuals per size classes on ordinate. The abscissa point corresponding to the projection of $50 \%$ of individuals on the curve gives the mean size at first maturity. From these curves, we can distinguish three categories of individuals according to the size [14]:

- L0: size below which no individual is mature;

- L50: size from which there is as many mature than immature individuals;

- L100: size at which all individuals are mature.

\subsection{Gonadosomatic Index (GSI)}

Gonadosomatic index (GSI) or "Gonadosomatic Report (RGS) is defined as the ratio of gonad weight to body weight percentage.

$$
R G S=\frac{W g}{W} \times 100
$$

$W g=$ gonad weight; $W=$ weight of the frog
We considered the eviscerated weight of the frog which presents the advantage of eliminating the gonad weight, the weight of digestive tract and its contents. A very higher ratio indicates a state of maturation advanced gonads. In contrast, a low ratio is in favor of sexual rest.

\subsection{Oocyte diameter and determination of the absolute fecundity}

The gonads are removed from pill dispensers and deposited on absorbent paper to remove the alcohol. They were then stripped of their envelope. These oocytes were then separated using pliers. The measurement of the diameter of the oocytes is conducted using a micrometer installed on a dissecting microscope. The measurement is taken on 30 oocytes selected by gonad. The absolute fecundity is obtained by counting all the oocytes effectively present in ovary using a manual particle counter.

Furthermore, the coefficient of variation was used as a test for homogeneity of the diameters of the oocytes. Its formula is as follows:

$C V=\frac{S}{\bar{X}} \times 100$

$C V=$ Coefficient of variation; $\bar{X}=$ average; $S=$ Standard deviation;

$C V<2 \%$ : the structure is very homogeneous,

$2 \%<C V<30 \%$ : the structure is homogenous,

$C V>30 \%$ : the structure is heterogeneous.

\section{Results}

\subsection{Size at first sexual maturity.}

The sizes at first sexual maturity studied in males and females of Hoplobatrachus occipitalis of the Banco National Park are illustrated in figure 2.

In this species, the sizes at first sexual maturity calculated (L50) is $124.5 \mathrm{~mm}$ in females (Figure 2A) against $95 \mathrm{~mm}$ in males (Figure 2B). The smallest mature individuals measure were $122 \mathrm{~mm}$ in females and $68 \mathrm{~mm}$ in males. All specimens reach sexual maturity at $130 \mathrm{~mm}$ in females and $120 \mathrm{~mm}$ in males.
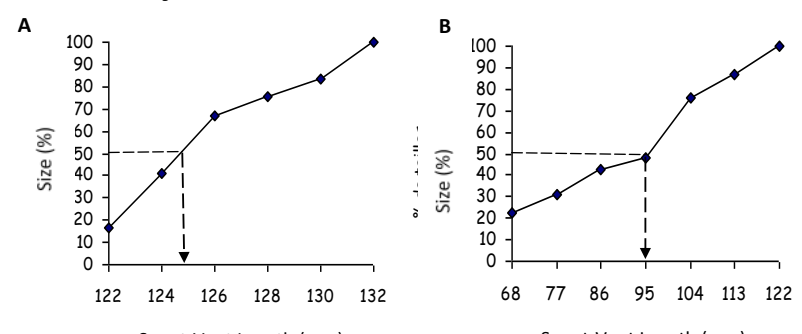

Figure 2: Variation in sizes at first sexual maturity in females (A) and males (B) of Hoplobatrachus occipitalis in the Banco National Park 


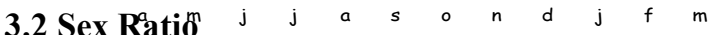

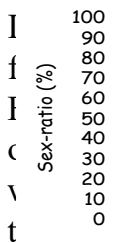

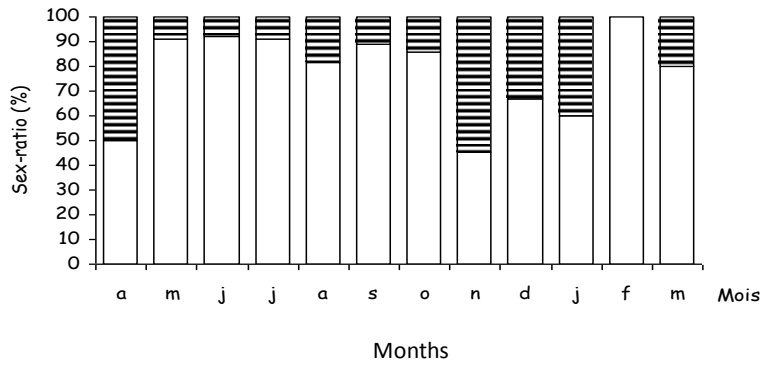

Figure 3: Monthly variation of the sex ratio in

Hoplobatrachus occipitalis from Banco National Park; shaded part of diagram represent females, non-shaded part represent males

\subsection{Gonadosomatic index (GSI)}

The variations of the GSI for males and females of $H$. occipitalis are indicated in Figure 4. In females (Figure $a$ ), the variations of GSI recorded in May (7.2 to $11.5 \%)$ and in March $(2.6$ to $7.9 \%)$ were significantly greater $(p>0.05$, Kruskal-Wallis"s test) than in June (4.7 to $5.5 \%)$. In males (Figure $b$ ), the variations of GSI in July $(0.08$ to $0.4 \%)$ and in April (0.1 to $0.2 \%)$ showed significant differences ( $p$ $<0.05$, Kruskal-Wallis"s test). However, the extreme monthly median values in females $(10.07 \%$ and $4.24 \%)$ and males $(0.36 \%$ and $0.01 \%)$ were observed respectively in October and August (females) and July and March (males).

\subsection{Fertility and oocyte diameter}

The diameters of 1110 oocytes from 37 ovaries were measured. The absolute fecundity is $3286 \pm 578$ oocytes and the average size of eggs is $2.74 \pm 0.43$. Regarding the coefficient of variation, it was $56.4 \pm 34.8$. Fecundity is slightly correlated to the body weight $(r>0.15)$ and SnoutVent Length ( $r>0.04)$.
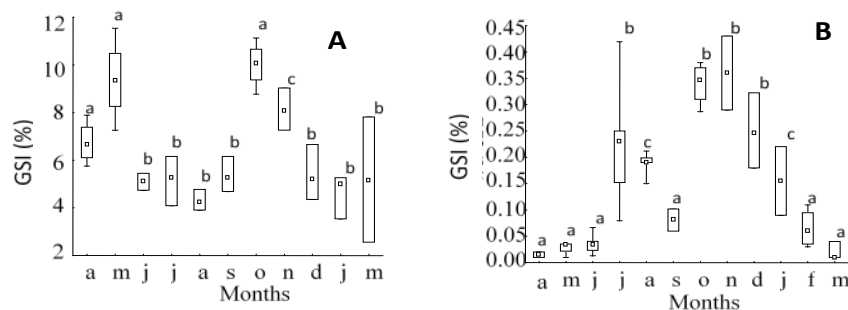

Figure 4: Monthly variations of GSI females (A) and males (B) of Hoplobatrachus occipitalis in Banco National Park; the medians of the box plots sharing the same letter $(\mathrm{a}, \mathrm{b}$ or

c) for the same GSI do not differ at $p>0.05$

Figure 5 illustrates the relationships between absolute fertility/Snout-Vent Length of the individual (Figure 5A) and absolute fertility/body weight (Figure 5B) in the various specimens.
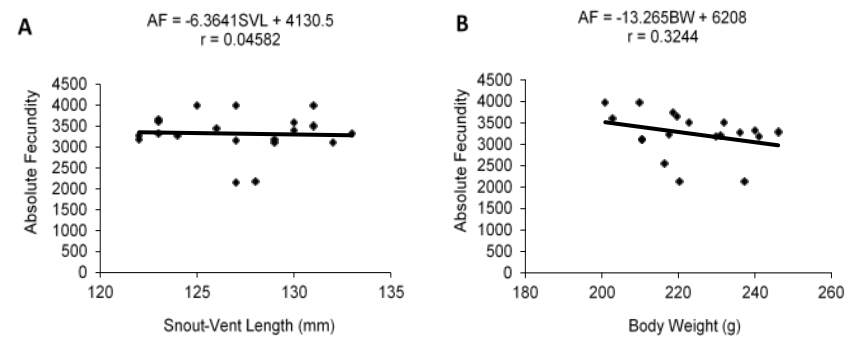

Figure 5: Relationship between absolute fecundity/SnoutVent Length (A) and absolute fecundity/body weight (B) in Hoplobatrachus occipitalis from Banco National Park

Relationship between body weight and gonad weight in Hoplobatrachus occipitalis were shown on figure 6. In this species, these two parameters are very weakly correlated $(\mathrm{r}=$ 0.0316).

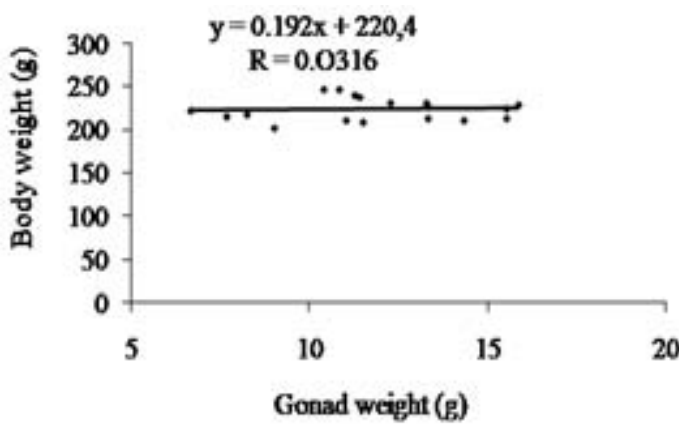

Figure 6: Variation in gonad weight $(\mathrm{Wg})$ relative to body weight $(\mathrm{Wb})$ in female of Hoplobatrachus occipitalis from the Banco National Park

\section{Discussion}

Hoplobatrachus occipitalis is a robust frog whose sizes at first sexual maturity and smallest mature individual are larger in females than in males. The males would then be most precocious than females. However, the literature available bring only information on the size of the smallest mature individual. Our values are higher than those observed by [7] in the Ivorian protected area "Comoé National Park" located in the north. Indeed, this author stated in this reserve that smaller mature specimens of this species have a size of 52 $\mathrm{mm}$ for males against $65 \mathrm{~mm}$ for female. These differences may be linked to temperature and humidity, two important factors which affect the reproduction in anurans [15]. In particular, BNP very watered with low temperature and high humidity would promote good growth in this species. This difference in mature size has already been observed in Ptychadena pumilio by [16]. This author found in the savanna reserve of Lamto (Ivory Coast) $36 \mathrm{~mm}$ in males and $41 \mathrm{~mm}$ in females from this species. Reproductive periods of the Crowned bullfrog extend from April to May and September to October with peaks located at the end of each period. It appears that the breeding period of the species is at the early rainy season. Indeed, the high temperatures of the end of dry seasons constitute a factor stimulating the ripening of oocytes. Laying the eggs which is closely related to water, 


\section{International Journal of Science and Research (IJSR) \\ ISSN (Online): 2319-7064}

Index Copernicus Value (2013): 6.14 | Impact Factor (2014): 5.611

could explain the different peaks observed in the rainy season (May, July and October). Sexual resting would be caused by excessive values of temperature and low values of relative humidity that characterize the dry seasons. Our results provide fairly good information on seasonal changes of the gonadosomatic index (GSI) and the breeding period of Hoplobatrachus occipitalis in the BNP. In amphibians, very few published data relevant to the GSI are available [17]. Our results indicate that in $H$. occipitalis, for breeding periods defined above, the proportions of males and females are nearly identical $(\operatorname{sex}$ ratio $=1 / 1)$ for the months corresponding to peaks. In addition, there is in frogs a territorialism. Thus, the song of male during the breeding period, while attracting female, tags territory against the approach of other males. That strategy which limits the competition for the conquest of the female by the male, could explain the high number of females during breeding periods. These breeding seasons present similarities with results from [18] obtained at Lamto (Ivory Coast) and [19] in South Africa. In Lamto savanna, [18] noted that breeding of anuran stops in December and January, which are rarely watered months. Indeed, drought inhibits all sexual activities as the croaking, the mating and egg laying. [19] reports that Ptychadena mascareniensis breeds during the rainy season. Furthermore, [20] indicate that females of $H$. occipitalis breed throughout the year in Ecuador. However, this activity according to these authors, is minimal from October to January, the dry season in this region is from December to February. Our observations overlap in part with reproduction periods defined by these authors. Indeed, with the exception of February where we have captured any female, mature females are frequent throughout the rest of the year. Crowned bullfrog has an average absolute fecundity of 3225 oocytes whose mean diameter is $2.7 \mathrm{~mm}$. These results are similar to those reported by [7] and [19]. Furthermore, [19] observed that females of $H$. occipitalis lay between 469 and 3752 eggs with diameters ranging between $2.9 \mathrm{~mm}$ and $3.7 \mathrm{~mm}$. As for [7], he observed oocyte diameter of around $3 \mathrm{~mm}$ in the Comoé National Park. However, our data differ from those obtained by [21] in the Outamba-Kilimi region in Sierra Leone where oocyte diameters range from 1.6 to $1.8 \mathrm{~mm}$. The average coefficient of variation is high (56.4) in $H$. occipitalis. This is in favor of the heterogeneous nature of the female gonad of that frog. This result is in favor of fractional oviposition in this frog. Our results corroborate those of [7], [19], [22] and [23].These authors noted at the moment of amplexus, the couple moves from a pond to another and the female lays small masses eggs in each of them.

Note also that in $H$. occipitalis, no relationship was obtained between absolute fecundity and Snout-Vent Length on one hand and body weight on other. Also, the change in the weight of the gonad is independent of the individual weight in this frog species. Thus, the taking of weight would be independent of the increase in weight of the gonad. No data to our possession deals with this relationship in amphibians. However, in fish, the taking of weight would be closely linked to food [13].

\section{Conclusion}

This study had permit to understand some traits of the reproduction of $H$. occipitalis from BNP. Thus, this species population was dominated by males. This frog has a yearly high reproductive potential due to its biology and the well environmental conditions of this protected area. To reduce overexploitation of this resource, a breeding program should be initiated in localities where people consume this frog.

\section{Acknowledgements}

We are grateful to the "Office Ivoirien des Parcs et Réserves" and the "Direction des Eaux et Forêts de Côte d"Tvoire" for the access permit to Banco National Park. The research permission was issued by the "Ministère de leenseignement Supérieur et de la Recherche Scientifique", of the Republic of Ivory Coast. This paper is part of the projects "BancoSanté-Ecologique" at the "Laboratoire d'Environnement et de Biologie Aquatique" of the Nangui Abrogoua University, Abidjan and the BIOLOG- program of the German Ministry of Education and Science (BMB+F; Project W08 BIOTA West, FZ 01 LC 00410). These supports are gratefully acknowledged.

\section{References}

[1] A.B. Onadeko, R.I. Egonmwan, J.K. Saliu, "Edible amphibian species: local knowledge of their consumption in southwest Nigeria and their nutritional value". West African journal of applied ecology, 19(1) pp. 67-76, 2011.

[2] M. Mohneke, A. B. Onadeko, M. O. Rödel, "Medicinal and dietary uses of amphibians in Burkina Faso". African journal of herpetology, 60 (1), pp. 78-83, 2011.

[3] G. Negroni, "Frog culture". World aquaculture, 28(1), pp. 16-22, 1997.

[4] B. Tohé, N.G. Kouamé, N.E. Assemian, G. Gourène, MO. Rödel, "Dietary strategies of the Giant Swamp Frog Hoplobatrachus occipitalis in degraded areas of Banco National Park (Ivory Coast)". International Journal of Scientific Research and Reviews, 3(2), pp. 34-46, 2014.

[5] B. Tohé, N.E. Assemian, N.G. Kouamé, G. Gourène, MO. Rödel, "Déterminisme des coassements des anoures de la ferme piscicole du Parc National du Banco (Côte d'Tvoire)". Sciences \& Nature, 5(1), pp. 71-79, 2008.

[6] F. Lauginie, Conservation de la nature et aires protégées en Côte d'Tvoire. Editions CEDA/NEI et Afrique Nature, 2007.

[7] M-O. Rödel, Herpetofauna of West Africa Vol. I Amphibians of the West African Savanna. Edition Chimaira, 2000.

[8] F., Kartas, J.P. Quignard, La fécondité des poissons tétéostéens. Masson (Collection biologie des milieux marins 5), Paris, 1984.

[9] C. Lévêque, P. Herbinet, "Caractères méristiques et biologiques des Schilbe mystus (pisces, Schilbeidae) en Côte d'Tvoire". Cahier de l'Orstom Série Hydrobiologie, 13 (3-4): 161-170, 1980.

[10] J.J. Albaret, Les poissons, biologie et peuplement. In : Environnement et ressources aquatiques de Côte 
d'Tvoire, Tome II (J. R. Durand, P. Dufour, Guiral, D. et Zabi, S. G. F., (éds.). Edition ORSTOM, 1994.

[11] M. Légendre, J. M. ECOUTIN, Aspects de la stratégie de reproduction de Sarotherodon melanotheron: comparaison entre une population naturelle (lagune Ebrié, Côte d'Tvoire) et différentes populations deélevage. In : Le troisième symposium international sur le tilapia en aquaculture (R.S.V. Pullin, J. Lazard, M. Légendre, J.B. Amon-Kothias, D. Pauly, (éds). Iclarm, CRO, ORSTOM, CIRAD. Manilla, Iclarm, Conf., Proc., 1996.

[12]B. Scherrer, Biostatistique. Louiseville, Gaetan Morin editeur, 1984.

[13] M. Ouattara, Stratégie de reproduction et réactions aux pressions de leenvironnement chez le poisson africain Mormyrops anguilloides et Marcusenius ussheri (Mormyridae), Schilbe mandibularis et $S$ intermedius (Schilbeidae) (Bassin Bia et Agnebi; Côte d'Tvoire). Thèse de Doctorat Université d'Abobo-Adjamé, Côte d'Tvoire, 2000.

[14] J. Moreau, Biologie et évolution des peuplements de Cichlidae introduits dans les lacs malgaches d'altitude. Thèse de Doctorat d'Etat de l'TNP Toulouse, France, 1979.

[15]J.C. Vignes, "Caractéristiques biologiques de la reproduction de la Grenouille rousse (Rana temporaria) dans une population à l"extrême sud-ouest de la France". Ciencias Naturales-Natur Zientziak, 58, pp. 131-148, 2010.

[16]M. Lamotte, "Le problème des Ptychadena (Fam. Ranidae) du groupe mascareniensis dans l'Ouest Africain". Bulletin du Muséum National d'Histoire Naturelle, 2 ${ }^{\mathrm{e}}$ Série, 39, pp. 647-656, 1967.

[17] Y.-C. Kam, T. C. Chen, J.T. YANG, K. M. YU, "Seasonal activity, reproduction, and diet of a Riparian frog (Rana swinhoana) from a subtropical forest in Taiwan". Journal of Herpetology, 32(3), pp. 447-492, 1998.

[18]R. BARBAULT, Les peuplements d'Amphibiens des savanes de Lamto (Côte d'Tvoire). Annale de 1,Université d,Abidjan, serie E, 5(1), pp 59-142, 1972.

[19]A. Channing, Amphibian of Central and Southern Africa. Cornell University Press, Ithaca, NY, 2001.

[20]E.R. Kühn, H. Gevaerts, G. Jacobs, G. Vandorpe, "Reproductive cycle, thyroxine and corticosterone in females of the giant swamp frog Dicroglossus occipitalis at the Equator". General and Comparative Endocrinology, 66, pp. 137-144, 1987.

[21] G.R. Zug, "Amphibians and reptiles of the OutambaKilimi region, Sierra-Leone". Journal of Herpetolology, 33, pp. 1-4, 1987.

[22] M. Spieler, K.E. Linsenmair, "Choice of optimal oviposition site by Hoplobatrachus occipitalis (Anura: Ranidae) in an unpredictable and patchy environment". Oecologia, 109, pp. 184-199, 1997.

[23] M. Spieler, K.E. Linsenmair, "Migration patterns and diurnal use of shelter in a ranid frog of a West African savannah: a telemetric study". Amphibia-Reptilia, 19, pp 43-64, 1998. 